\title{
Función y Símbolo del Hijo en el Ismaelillo de Martí
}

E L propósito de este estudio es el de analizar el Ismaelillo de José Martí, libro que se considera una de las claves en la génesis del movimiento modernista. Antes de entrar en materia creemos necesario aclarar lo que ha de cntenderse por función y símbolo; además, conviene establecer cuál es la naturaleza del hijo de Martí tal como la concibe el poeta.

Por función entendemos el efecto que tiene el hijo sobre la materia poética y el poeta. Este efecto surge de la naturaleza del hijo, quien se caracteriza por su pureza $e$ inocencia sin par. Son tres las funciones principales que ejerce el hijo sobre el poeta: la de dominio y protección, la de consuelo y la de inspiración. Todos los poemas de la colección caben dentro de una o más de estas categorias y el hijo está presente explícita o implícitamente en todas las poesías.

Por simbolismo entendemos un signo o sistema de signos que repre. sentan un significado pero que a la vez tienen valor en sí mismo. "In literary theory, it seems desirable that the word [symbol] should be used in this sense: as an object which refers to another object but which demands attention also in its own right, as a presentation". ${ }^{1}$ Generalmente el simbolo no señala con precisión su significado. En cambio, sugiere un tono, una cualidad o una actitud. Tal es el caso del simbolismo del Ismaelillo, como se observará en el curso de este trabajo.

Antes de analizar las tres funciones del hijo en el Ismaelillo, debemos concretar la naturaleza del hijo y los símbolos que acompañan e ilustran esta naturaleza.

Uno de los temas más persistentes en el Ismaelillo es el de la puteza $e$ inocencia del hijo del poeta. Desde la descripción física hasta la moral

1 Rene Wellek y Austin Warten, Theory of Literature (New Yotk: 1956). p. 178. 
y espiritual el hijo aparece como el paradigma de lo puro, de lo sencillo e inocente. Por eso, sin duda, el poeta utiliza tantas veces el color blanco, que tradicionalmente simboliza la castidad $y$ lo moralmente limpio. Schulman observa que a partir de 1875 Martí empieza a conferir a blanco "valores tradicionales en este color dentro de la escala cromática del mun. do occidental: pureza, castidad, perfección y belleza moral".2 Según Schulman, el empleo del blanco como símbolo de pureza e inocencia es de un valor sumamente artístico en el 7 smaelillo. Aparece repetidas veces a lo largo del volumen como un leit-motif cuya función es sugerir la eterna presencia del hijo y su influencia purificadora. ${ }^{3}$

En el primer poema de la colección habla Marti del "hombro blanco" 8 "las guedejas rubias y blancas" de Ismael. Luego, en "Musa traviesa", insiste otra vez en la pureza del hijo cuando el padre duda si el cuerpo de. Ismaelillo es de carnes o nácares. En "Mi reyecillo" se encuentra el color blanco reforzado por otros dos adjetivos descriptivos que aumentan la cualidad vigorosa e inocente del hijo. Aqui el hijo se representa como "desnudo, blanco y rollizo". El desnudo es símbolo de la sencillez sin adornos. La característica de ser rollizo, que se asocia con la sana y vigo. tosa robustez de los niños, intensifica la sencillez natural referida por el blanco. Así, el hijo resulta ser sencillo, puro y de una gran vitalidad innata.

Además, el empleo del diminutivo en el Ismaelillo contribuye al sentido de sencillez y pureza que quiere producir el poeta. Amado Alonso en su estudio sobre la estética del diminutivo distingue entre los diminutivos afectuosos y los de carácter representacional y destacador. Los de la primera categoría tienen la función de encariñar un objeto amado. Los otros, en cambio, pueden dar una representación imaginativa del objeto.4. El diminutivo en el Ismaelillo parece participar de ambas funciones. Por ejemplo, cuando Martí habla de su "diablillo", s todo lo malo de diablo se quita con el diminutivo. El hijo es un diablo no malo sino travieso $y$ simpático. Aquí tenemos que ver con un diminutivo afectuoso. Pero, al mismo tiempo es un diminutivo representacional y destacador. Según. Amado Alonso el diminutivo de este último tipo nos hace parar "en la representación imaginativa del objeto, pero ahora poniendo el dedo sobre su 'valor', o más exactamente, sobre lo valioso que nos es... es una.

2 Ivan A. Schulman, Simbolo y color en la obra de José Martí (Madrid, 1960), P. 484 .

3. Ibid., p. 484.

4 Amado Alonso, El articulo y el diminutivo (Universidad de Chile, 1937), p. 55.

Ibid. 
contemplación del objeto como valioso".6 Esto es precisamente lo que quicre lograr el poeta con el ya citado diminutivo. El hijo le es valioso porque es un diablillo benigno, un "diablillo con alas de ángel"." Angel, como se ve, en este caso trasmite simbólicamente las ideas de pureza e inocencia. Además, dentro del sistema simbólico de Marti la palabra alas, según Schulman, es un simbolo de idealismo ascendente que indica altura $y$ elevación. ${ }^{8}$ Así, la palabra "diablillo" queda depurada de todo lo malo que podria significar.

Varias veces la sencillez del hijo se encuentra en yuxtaposición con un elemento bajo, sensual o lujurioso. Este fenómeno ha sido estudiado e identificado por Schulman como un procedimiento de polaridad. 9 En tales casos la pureza no sólo sirve de contraste para lo inmoral, sino que esto último hace destacar aún más lo elevado del hijo porque es él quien siempre sale vencedor sobre las bajas condiciones humanas. En "Brazos fragantes" lo sencillo y puro se encuentra frente a frente con lo sensual. El poeta se ve seducido por los brazos fragantes y sensuales de una mujer, pero él los rechaza, prefiriendo el amor casto y espiritual de su hijo: "Y" yo doy los redondos/Brazos fragantes/por dos brazos menudos..." 10 El amor del hijo se encuentra en un plano más alto y espiritual que el de la mujer. El goce de este amor es más bien místico que sensual. Dice el poeta que estos brazos saben halarle y labrarle un collar de mís. ticos lirios. Lo mismo ocurre en el poema titulado "Tórtola blanca", donde el poeta rechaza los placeres de una orgía bacanal precisamente porque el hijo aparece llamándole desde la ventana. Explica Eugenio Florit: "Y aquí tras lograr un cuadro bellísimo, cuadro de agitación de una fiesta - ejemplar pintura de color y movimiento- rechaza el poeta 'la copa labrada' porque la visión del hijo, símbolo de pureza, se le aparece en el balcón; aquellas alitas blancas llenas de miedo le llaman rescatándolo así de caer en el vértigo del vals". " ${ }^{11}$ a tórtola, símbolo tradicional del amor casto y puro, encarna la esencia del hijo $y$ salva al poeta.

Resulta muy parecido el caso del poema titulado "Mi despensero":

¿Qué me das? ¿Chipre?

Yo no lo quiero: 1962).

6 José Marti, "Musa traviesa", Versos (Ed. Eugenio Florit, New York,

7 Ibial

- Schulman, op. cit., pp. 131-140.

9 Ibid., pp. 82-94.

10 Martí, op. cit., "Brazos fragantes".

II Eugenio Flotit, "Los versos de Marti", Eatudio preliminar de Versos de Marti. 
$\mathrm{Ni}$ rey de bolsa

$\mathrm{Ni}$ posaderos

Tienen del vino

Que yo deseo;

$\mathrm{Ni}$ es de cristales

De cristaleros

La dulce copa

En que lo bebo.

Más está ausente
Mi despensero,
Y de otro vino
Yo nunca bebo.

Otra vez el poeta rehusa los bienes mundanales y sus placeres porque no satisfacen su sed. Es otro el vino que él apetece y él no prueba de las tinajas de este mundo. El padre queda vencido por el amor puro y casto de su hijo, el cual no le fuerza, no le vence por las armas duras porqud sus armas no son de acero sino de plumas.. ${ }^{12}$ Aquí, además del contraste en el plano físico entre lo duro del acero y lo blando de las plumas, el primero es símbolo de la fuerza brutal y material. En cambio, las plumas simbolizan una persuación cariñosa y espiritual.

Son muchos los otros símbolos referentes a la pureza del hijo: "ma. riposa", 13. "blanco, pálido ángel" 14 que "deja rumor de alas de ave", 15 todos los cuales indican una cualidad de elevación etérea y llevan im. plícitos en si las ideas de inocencia y pureza sublimes.

Ya que hemos establecido cuál es la naturaleza poética del hijo de Martí, veamos ahora las tres funciones que él ejerce dentro de los poemas.

Corona: el bijo como guerrero y monarca

En el poema titulado "Príncipe enano" encontramos claramente enunciadas las tres funciones del hijo dentro del Ismaelillo: "El para mi es corona,/almohada, espuela".

Schulman observa que en la obra de Martí corona es símbolo de la capacidad del hombre de levantarse por encima de si mismo, de mejorar y ennoblecerse. "Darío interpreta sagazmente el valor intelectivo de las

12 Marti, op. cit, "Musa traviesa".

13 Ibid.

14 Marti, op. cil., "Amor errante".

15 Marti, op. cit., "Tábanos fieros". 
tres figuras poéticas, asegurando a corona el significado de triunfo, a almobada el de reposo y a espuela el de impetu. Un rasgo concomitante de estas imágenes lo tenemos en el empleo del término de realeza prín. cipe para teferirse al hijo. Este término posee contenido semejante en caballero, reyecillo y monarca, todos los cuales se usan de manera análoga en Ismaelillo aplicados a su descendencia". ${ }^{16}$

Sirve el hijo de guardián. y protector espiritual para su padre. Cita. mos del poema titulado "Hijo del alma":

Guardiancillo magnánimo,

La no cerrada

Puerta de mi hondo espiritu

Amante guardas...

Le protege a su padre de sus penas y no deja que entren en su espiritu, como se ve otra vez en el mismo poema:

$Y$ si en la sombra oculta

Búscanme avaras,

De mi calma celosas,

mis penas varias,

En el umbral oscuro

Fiero te alzas,

$¡ Y$ les cierran el paso

Tus alas blancas!

Aquí las alas son símbolo de protección y abrigo y su blancura (pureza) forma contraste con las oscuras sombras en que se esconden las penas.

Cuando le atacan al padre las tentaciones del mundo, él no teme nada porque sabe que su hijo le protegerá. Será su escudo y su espada, como se ve, por ejemplo, en "Tábanos fieros":

No temo yo ni curo

De ejércitos pujantes,

Ni tentaciones sordas,

$\mathrm{Ni}$ vírgenes voraces:

El vuela en torno mío,

El gira, él para, él bate;

Aqui su escudo opone;

Alli su clava blande;

16 Schulman, op. cit., pp. 186-188. 
Y a diestra y a siniestra

Mandobla, quiebra, esparce;

Recibe en su escudillo

Lluvia de dardos hábiles;

Sacúdelos al suelo,

Bríndalo a nuevo ataque.

Nos explica Schulman el significado de escudo, espada y lanza en este pasaje: "En ninguna parte está expresado con mayor viveza este contraste con las fuerzas contaminadoras de la vida que en 'Tábanos fie. ros'. Por medio de imágenes como 'tábanos fieros' y 'chacales' que en. carnan los elementos innobles del mundo, el poeta los reta estoicamente a atacarle, seguro de poderlos absorber en su invasión porque cuenta con la protección y amor (escudo) de Ismaelillo... El escudo, arma defen. siva, emblema de la justicia y de la virtud, está contrastado aquí con dos formas simbólicas de la agresividad: lanza y espada. Como se ha indicado antes, ambas representan la participación de Martí en la revolución que otorgará al hombre su redención final"'. ${ }^{17}$ De modo que el hijo es a la vez protector y agresor: protege al padre; pone en huida a las huestes enemigas; y ayuda a Martí a avanzar hacia la justicia. El hijo es el apoyo y el sostén de su padre. Citamos del mismo poema: "Hijos, escudos fuertes,/De los cansados padres!"

Como siervo sumiso, el padre responde a este amor protector ju. rando lealtad y reconociendo a su hijo como su señor. Es un tirano el príncipe enano, este reyecillo que es monarca del pecho de su padre. Pero no es como los otros reyes y tiranos porque él domina con el amor y su cetro es un beso. Citamos de "Mi reyecillo":
Mas yo vasallo
De otro rey vivo,
Un rey desnudo,
Blanco y rollizo:
Su cetro $\rightarrow$ iun beso!
Mi premio - jun mimo!
Toca en mi frente
Tu cetro omnímodo;
Ungeme siervo,

17 lbid., pp. 282-283. 
Siervo sumiso:

Lealtad te juro,

¡Mi reyecillo!

Este monarca ejerce un dominio absoluto en el corazón del poeta y le hace pasar por una metamorfosis. Como dice Martí en "Musa traviesa": " Hijo soy de mi hijo!/`El me rehace!"

En "Valle lozano" el poeta nos revela el medio de esta transforma. ción: el amor. En este poema el hijo se compara con un labriego que ha transformado milagrosamente en campo florecido lo que antes era un campo estéril e infecundo. El poeta le pregunta al labriego, o sea al hijo, de qué flores ha untado el arado y de qué río ha regado el prado para que así florezca. Claro, el campo verde es símbolo del pecho del padre, un pecho que todos han arado con dagas, pero el hierro del hijo no hace daño. Como respuesta a las preguntas del poeta el hijo le trae un beso casto. Es el amor que lo ha transformado.

Pasa lo mismo en el poema "Rosilla nueva", en donde el poeta pregunta: "iTraidor! ¿Con qué arma de oro/Me has cautivado?" Aquí el poeta se equipara con un peñasco inmóvil, pero en presencia de su hijo se derrite como la nieve:

Y así como la nieve,

Del Sol al blando

Rayo, suelta el magnífico

Manto plateado,

$Y$ salta en hilo alegre

Al valle pálido

$Y$ las rosillas nuevas

Riega magnánimo;

Así, guerrero fúlgido,

Roto a tu paso,

Humildoso y alegre

Rueda el peñasco;

$Y$ cual lebrel sumiso

Busca saltando

A la rosilla nueva

Del valle pálido.

Este amor filial se convierte en un amor mucho más universal y 
social en el poema titulado "Amor errante". Aquí el "blanco, pálido ángel" busca a quién amparar y socorrer. Inconsolable, siente ganas de llorar al ver que no puede sacrificarse por alguien. El hijo no sỏlo ins. pira un amor familiar e íntimo sino también un amor humanitario mo. tivado por los problemas sociales.

\section{ALmoHADA: EL HyJo COMO CONSOLADOR}

Es el hijo quien, montado sobre el cuello de su padre, acompaña espiritualmente a éste por todas partes y no lo abandona en medio de las tormentas de la vida, como se observa en el poema titulado "Sueño despierto":

Yo sueño con los ojos

Abiertos, y de dia

$Y$ noche siempre sueño.

$\mathrm{Y}$ sobre las espumas

Del ancho mar revuelto,

$Y$ por entre las crespas

Arenas del desierto,

$Y$ del león pujante,

Monarca de mi pecho,

Montado alegremente

Sobre el sumiso cuello,

Un niño que me llama

¡Siempre flotando veo!

Cuando sufre el poeta de una interna tormenta, su hijo le consuela con un beso. En medio del insoportable camino de la vida, el padre tiende la mano en busca de apoyo y su hijo le da otro beso invisible. ${ }^{1 a}$ Algunas veces el hijo ejerce función de consolador y otras veces le of rece a su padre un alivio más amplio. Cuando el poeta baja de sus sueños graves es al hijo a quien primero encuentra en las regiones aéreas. Es Ismaelillo quien despierta a su padre de estos sueños pesados y llega como una ráfaga de aire que lo refresca todo, como vemos, por ejemplo, en "Musa traviesa":

Suavemente la puerta

Del cuarto se abre,

18 Martí, op. cit., "Sobre mi hombro". 
$Y$ éntranse a él gozosos

Luz, risas, airc.

Al par da el Sol en mi alma

$Y$ en los cristales.

Aquí la luz, las risas y el aire son simbolos de frescura, de alivio y de renovación surgidos por la entrada del hijo.

El poeta mismo necesita y pide esta interrupción en sus quehaceres espirituales. Como Unamuno atormentado por sus dudas pide un momento de tregua en su lucha interior, así José Marti, sumergido en el abismo de los problemas humanos, anhela un rato de gozo y de reposo. Otra vez nos referimos a "Musa traviesa":

\section{Venga, $y$ por cauce nuevo \\ Mi vida lance, \\ $Y$ a mis manos la vieja \\ Péñola arranque, \\ $Y$ del vaso manchado \\ ¡La tinta vacíe!}

Es Schulman quien explica la función paliativa del hijo tal como se ve en la idea de almobada en los ya mencionados versos de "Príncipe cnano": "Este símbolo de contraste representa el ansia del poeta por alcanzar un descanso, un momento de tranquila soledad, en su lucha contra las fuerzas maléficas y egoístas". 19

\section{Espuela: el Hijo como Fuerza Vital}

Otro aspecto del hijo que se revela en esta colección es el de su fuerza vital. El hijo no tiene nada de estático ni de pasivo. Es, en cambio, activo, robusto y enérgico y un verdadero manantial de vitalidad y vigor. Sus ojos "vuelan, brillan, palpitan y relampaguean".20 Su rica sangre anima la sangre agotada de su padre. ${ }^{21}$ Es la luz en la oscuridad, 22 una "abeja que zumba" y "rompe y mueve el aire".23 Es musa y despensero para su padre.24 En fin, es la fuente inacabable de inspiración y acción en donde bebe Martí. Su presencia trae un vuelo que lleva consigo a su

19 Schulman, op. cit., p. 294.

$\infty$ - Martí, op. -it., "Príncipe enano".

21 Ibid.

22 Ibid.

23 Marti, op. cit., "Tábanos fieros".

24 Marti, op. cit., "Musa traviesa" i "Mi despensero". 
padre.25 Al pasar el hijo, siente Martí dentro de si un "inquieto mar joven", una "manada alegre de bellos potros vivos" que hacen desbordar su generoso espíritu. ${ }^{26}$

Es Ismaelillo quien espolea e instiga al padre hacia la acción. El hijo quiere que su padre vuelva a luchar y a vivir. En los ya citados versos de "Príncipe enano", espuela es sinónimo de aguijón o empuje que pro. duce impetu y acción. Es frecuente el uso de esta y otras palabras rela. cionadas con el caballo. El hijo es un "caballero", "caballeruelo", "caballero del aire". o "jinetuelo" que cabalga en las ondas de la luz matinal o que se pone de horcajadas sobre el pecho de su padre al des. pertarle por la mañana. Citamos del poema "Mi caballero":

Por las mañanas

Mi pequeñuelo

Me despertaba

Con un gran beso.

Puesto a horcajadas

Sobre mi pecho,

Bridas forjaba

Con mis cabellos.

Ebrio él de gozo,

De gozo yo ebrio,

Me espoleaba

Mi caballero:

¿Qué suave espuela

Sus dos pies frescos!

¡Cómo reía

Mi jinetuelo!

$Y$ yo besaba

Sus pies pequeños,

¡Dos pies que caben

En solo un beso!

El hijo. le sirve al padre como espolón, le despierta de la inercia y le impulsa a obrar.

En conclusión, podemos decir que todos los poemas del Ismaelillo forman una unidad orgánica alrededor de las tres funciones del hijo

26 Marti, op. cit., "Penachos vividos". 
enunciadas en el primer poema, "Príncipe enano", al cual podemos considerar como prólogo poético del volumen. Estas tres funciones (pro. tección, consuelo e inspiración) determinan cl contenido de los poemas y rigen los símbolos que representan al hijo a lo largo de la colección.

Gene M. Haxmitt

Allegbeny College 
